\title{
Shift of low to high nucleic acid bacteria as potential bioindicator for the screening of anthropogenic effects in the receiving river due to palm oil mill effluent final discharge
}

\begin{abstract}
The microbiological effects of palm oil mill effluent (POME) final discharge upon a receiving river were assessed in this study by using the nucleic acid double staining assay based on flow cytometry. The functional status of the bacterial community at the single-cell level was determined with regards to their abundance, viability and nucleic acid content to monitor the effects of POME final discharge on the affected river. The effluent resulted in the increment of the total cell concentration (TCC) and viable cells which were correlated with the increment of biological oxygen demand (BOD5) and total organic carbon (TOC) concentrations in the receiving river. The shift of low nucleic acid (LNA) to high nucleic acid (HNA) bacterial cells in the affected river suggested the transformation of dormant to active cells due to the POME final discharge. This is the first study to report on the shift of LNA/HNA ratios which may serves as a potential bioindicator in the screening of the anthropogenic effects due to POME final discharge in river water with originally high LNA proportions. Monitoring the effluent discharge at low trophic level using flow cytometry is a rapid and sensitive approach when compared to the current physicochemical assessment method. This approach allows for the screening of river water contamination caused by POME final discharge prior to a full assessment using the recently proposed specific bacterial indicators.
\end{abstract}

Keyword: Bacterial community; Palm oil mill effluent; Wastewater effluent; High nucleic acid bacteria; Low nucleic acid bacteria; Flow cytometry 